OPEN ACCESS

Edited by:

Andreas Teufel,

Medical Faculty Manheim, University

of Heidelberg, Germany

Reviewed by:

Simona Bertoni,

Università degli Studi di Parma, Italy

Viktória Venglovecz,

University of Szeged, Hungary

*Correspondence:

Chunmei Li

chunmeili@njau.edu.cn; lichunmei74@gmail.com

Specialty section:

This article was submitted to

Gastrointestinal Sciences,

a section of the journal

Frontiers in Physiology

Received: 20 April 2017 Accepted: 08 December 2017 Published: 19 December 2017

Citation:

Tang J, Hu P, Li Y, Win-Shwe T-T and Li C (2017) Ion Imbalance Is Involved in the Mechanisms of Liver Oxidative Damage in Rats Exposed to

Glyphosate. Front. Physiol. 8:1083. doi: 10.3389/fphys.2017.01083

\section{Ion Imbalance Is Involved in the Mechanisms of Liver Oxidative Damage in Rats Exposed to Glyphosate}

\author{
Juan Tang ${ }^{1}$, Ping $\mathrm{Hu}^{1}$, Yansen $\mathrm{Li}^{1}$, Tin-Tin Win-Shwe ${ }^{2}$ and Chunmei $\mathrm{Li}^{1 *}$ \\ 1 Jiangsu Province Key Laboratory of Gastrointestinal Nutrition and Animal Health, College of Animal Science and \\ Technology, Nanjing Agricultural University, Nanjing, China, ${ }^{2}$ Health Effect Assessment Section Center for Health and \\ Environmental Risk Research, National Institute for Environmental Studies, Tsukuba, Japan
}

Glyphosate (N-phosphonomethyl-glycine, GLP) is the most popular herbicide used worldwide. This study aimed to investigate the effects of glyphosate on rats' liver function and induction of pathological changes in ion levels and oxidative stress in hepatic tissue. Sprague-Dawley rats were treated orally with $0,5,50$, and $500 \mathrm{mg} / \mathrm{kg}$ body weight of the GLP. After 5 weeks of treatment, blood and liver samples were analyzed for biochemical and histomorphological parameters. The various mineral elements content in the organs of the rats were also measured. Significant decreases were shown in the weights of body, liver, kidney and spleen between the control and treatment groups. Changes also happened in the histomorphology of the liver and kidney tissue of GLP-treated rats. The GLP resulted in an elevated level of glutamic-oxalacetic transaminase (GOT), glutamic-pyruvic transaminase (GPT) and IL-1 $\beta$ in the serum. Besides, decreased total superoxide dismutase (T-SOD) activity and increased malondialdehyde (MDA) contents in the serum, liver, and kidney indicated the presence of oxidative stress. Moreover, increase of hydrogen peroxide $\left(\mathrm{H}_{2} \mathrm{O}_{2}\right)$ level and catalase (CAT) activity in the serum and liver and decrease of glutathione (GSH) and lutathione peroxidase (GSH-Px) activity in the kidney tissue further confirmed the occurrence of oxidative stress. The results of RT-PCR showed that the mRNA expressions of $I L-1 \alpha, I L-1 \beta, I L-6, M A P K 3, N F-\kappa B$, SIRT1, $T N F-\alpha$, Keap1, GPX2, and Caspase-3 were significantly increased in the GLP-treated groups compared to the control group. Furthermore, PPAR $\alpha$, DGAT, SREBP1C, and SCD1 mRNA expressions were also remarkably increased in the GLP-treated groups compared to the control group. In addition, aluminum (Al), iron (Fe), copper (Cu), zinc (Zn), and magnesium (Mg) levels were showed a significant difference reduction or increase in rat liver, kidney, spleen, lung, heart, muscle, brain, and fat tissues. These results suggested that glyphosate caused obvious damage to rats' liver and caused various mineral elements content imbalances in various organs of rats. Ion imbalance could weaken antioxidant capacity and involve in the mechanism of liver oxidative damage caused by GLP.

Keywords: ion, oxidative stress, liver, glyphosate, rat 


\section{INTRODUCTION}

Glyphosate (GLP) is a non-selective, post-emergence herbicide used for weed control in various crops, especially in rice, maize and soybean (Coutinho et al., 2005). Eighty percent of genetically modified crops were GLP-resistant plants, such as corn, soy, cotton and canola and so on (Williams et al., 2000). American farmers have widely used anti-GLP crops since 1996 (Frisvold et al., 2010). It means there will be much more glyphosate in soil and water environment. Study has reported that GLP and its metabolite such as aminomethylphosphonic acid (AMPA) and formaldehyde were found in the soil and rivers (Temple and Smith, 1992). It has been extensively demonstrated that exposure to GLP leads to oxidative stress in several tissue, including the livers and kidneys (Beuret et al., 2005; El-Shenawy, 2009; Modesto and Martinez, 2010; Larsen et al., 2012; Cattani et al., 2014).

GLP can chelate the iron ( $\mathrm{Fe})$ and aluminum (Al), which interferes with ion assimilation in the plant (Eker et al., 2006; Bellaloui et al., 2009). GLP also change the ion levels in fish by chelated with them (Ayoola, 2008; Samsel and Seneff, 2013). Al is widespread in soil, water, and air, and is also the most widely used metal by humans (Kumar and Gill, 2009). Al is mainly absorbed by the gastrointestinal tract and easily accumulates in liver cells and organelles (e.g., macrophages and lysosomes) (Krewski et al., 2007; Kumar and Gill, 2009). Some scholars believe that $\mathrm{Al}$ accumulation does not causes significant hepatotoxicity, because it can be eliminated by hepatocytes (Li et al., 2011). However, most studies reported that $\mathrm{Al}$ causes central nervous system toxicity, hepatotoxicity, nephrotoxicity, cardiotoxicity and osteoporosis to body tissue (Crisponi et al., 2013; Geyikoglu et al., 2013). Iron (Fe) is not only an important micronutrient, but also a redox reaction of the biocatalyst, and when the transition metal reaches the transition level, is conducive to the production of reactive oxygen species (Aust et al., 1985). Zinc $(\mathrm{Zn})$ as an antioxidant, involved in cell membrane stabilization, copper/zinc superoxide dismutase (Cu/Zn SOD) structure and metallothionein induction. Zn deficiency can damage the oxidant defense system and cause oxidative damage to cells or tissue (Oteiza et al., 1999). Therefore, it is important to study whether GLP can effects the ion content in the liver and other organs of rats.

The aim of this study was designed to evaluate liver histomorphological changes, oxidant/antioxidant status, levels of inflammatory markers, lipid metabolism factors, and to investigate ion levels of $\mathrm{Al}, \mathrm{Fe}, \mathrm{Cu}, \mathrm{Zn}$, and $\mathrm{Mg}$ ion levels in GLPexposed rats' liver tissues. The specific mechanism between liver and other organs damage and ion imbalance need to be further studied.

\section{MATERIALS AND METHODS}

\section{Chemicals}

Glyphosate, N-(phosphonomethy) glycine (GLP), was purchased from Shanghai Ryon Biological Technology Co. Ltd (Shanghai, China).

\section{Animals and Ethic Statement}

Eight week-of-age male Sprague-Dawley rats weighting $180-220 \mathrm{~g}$ were purchased from the Nanjing Qinglongshan Experimental Animal Center (Nanjing, China). Prior to experiment, all rats were allowed to acclimate for at least 1 week. All rats were housed in separate cages under environmental conditions $\left(23 \pm 2{ }^{\circ} \mathrm{C}, 50 \pm 10 \%\right.$ relative humidity, 12-h light: dark cycle) and had unrestricted access to food and water throughout the period of the study. Animal care and use were conducted in accordance with the National Institute of Health Guidelines for Animal Care and the Committee of Animal Research Institute, Nanjing Agricultural University, China. At the same time, the study also received ethical approval from the committee.

\section{Animal Treatment and Sample Collection}

Rats were randomly assigned to 4 groups ( $n=8$ /group). The rats were orally administered with glyphosate $(5,50$, and 500 $\mathrm{mg} / \mathrm{kg}$ body weight) daily for 35 days at 9 AM. Glyphosate dose selection was according to GLP no-observed adverse effect level (NOAEL) of $1,000 \mathrm{mg} / \mathrm{kg} /$ day for developmental toxicity (Williams et al., 2000) and equivalent to $1 / 1,000,1 / 100$, and 1/10 of LD 50 in rats (Larini, 1999; Benedetti et al., 2004). GLP was orally administered at a volume of $0.5 \mathrm{ml} / \mathrm{kg}$. Rats orally administered with distilled water were used as the control group. Twenty four hours after the last gavage, rats were weighed and decapitated. Blood samples were collected from the jugular vein and placed at $37^{\circ} \mathrm{C}$ for $1 \mathrm{~h}$ before being centrifuged $(3,500 \mathrm{rpm}$, $15 \mathrm{~min}, 4^{\circ} \mathrm{C}$ ) for biochemical assays. The liver, kidney, spleen, heart, lungs, brain, adrenal glands, muscle and fat tissue were collected, rinsed twice in phosphate-buffered saline (PBS pH 7.4), use the filter paper to dry the PBS and then accurately weigh and weighed for further examinations. One piece of liver and right kidney was used for morphometric analysis and another piece was used to prepare homogenates for analyses of tissue oxidative indexes, or frozen in liquid nitrogen for subsequent qualitative reverse transcription polymerase chain reaction (RT-PCR). The organ index is calculated as follows:

\section{Organ index (g/gBW)}

$$
=\text { Organ absolute weight }(\mathrm{g}) / \text { Body weight }(\mathrm{g}) \times 100 \%
$$

\section{Histological Preparation}

Samples of tissue (livers and kidneys) were obtained from the animals and fixed in $4 \%$ formaldehyde solution for $24 \mathrm{~h}$ then dehydrated in an ascending series of alcohol, clarified using xylene, and embedded in paraffin. Paraffin were sectioned into $5 \mu \mathrm{m}$ slices and stained with hematoxylin-eosin (HE) for microscopic examination. The score system was used to evaluate the hepatic and renal damages (Ishak et al., 1995; Zheng et al., 2005; Klopfleisch, 2013). Briefly, the scores of liver sections graded on a $0-4$ scale for lobular inflammation, focal necrosis and mononuclear cell infiltration, and kidney graded on a $0-4$ scale for proximal and distal tubular necrosis, glomerular cellularity, and glomerular necrosis (where 0 represents no abnormality, and $1,2,3$, and 4 represent mild, moderate, moderately severe, and severe abnormalities, respectively). 


\section{Biochemical Evaluation}

For enzymes determination, the suspension of liver, kidney and the blood samples were centrifuged at 3,500 rpm for $15 \mathrm{~min}$. The homogenate and serum were collected and used for liver function assessment including measurements of the enzymes glutamicoxalacetic transaminase (GOT), glutamic-pyruvic transaminase (GPT), total superoxide dismutase (T-SOD), malondialdehyde (MDA), hydrogen peroxide $\left(\mathrm{H}_{2} \mathrm{O}_{2}\right)$, catalase (CAT), glutathione (GSH), glutathione peroxidase (GSH-Px). The activities of SOD, $\mathrm{H}_{2} \mathrm{O}_{2}, \mathrm{CAT}, \mathrm{GSH}, \mathrm{GSH}-\mathrm{Px}$, and the content of MDA were assayed using commercial reagent kits obtained from the Institute of Biological Engineering of Nanjing Jiancheng (Nanjing, China) following the manufacturer's instructions. All operations were done at $4^{\circ} \mathrm{C}$.

Analyses of the SOD activity was based on SOD-mediated inhibition of nitrite formation from hydroxyammonium in the presence of $\mathrm{O}^{2-}$ generators (xanthine/xanthine oxidase) (Elstner and Heupel, 1976). The total SOD activity expressed as U/mg protein. MDA was evaluated by thiobarbituric acid reactive substances method (TBARS) and expressed as nmol/mg protein (Draper and Hadley, 1990). GSH-PX activity was estimated by the analysis of reduced GSH in the enzymatic reaction (Sedlak and Lindsay, 1968). GSH-PX activity was expressed as U/mg protein. CAT activity was assayed by the method developed by Aebi (Aebi, 1984), and calculated as $\mathrm{nM} \mathrm{H} 2 \mathrm{O} 2$ consumed/min/mg of tissue protein. Protein concentrations in the supernatant were measured according to the Coomassie Brilliant Blue method. The activity of serum GOT and GPT was assayed according to the method that usually used in clinical examination (Reitman and Frankel, 1957).

\section{Serum Cytokine Measures}

Serum levels of IL-1 $\beta$ and IL- 6 were determined using a commercially available enzyme-linked immunosorbent assay (ELISA) kit purchased from R\&D Systems (Shanghai, China). The results were expressed as $\mathrm{pg} / \mathrm{mL}$.

\section{Quantitative RT-PCR (qRT-PCR) Analysis}

Total RNA was extracted from the tissue using the reagent box of Total RNA Kit (Invitrogen, Carlsbad, CA, US), according to the manufacturer's instructions. The concentration of RNA was measured by using a spectrophotometer and the purity was ascertained by the A 260/A 280 ratio with a Nanodrop ${ }^{\circledR}$ 8000. Total RNA from each sample was reverse transcribed to cDNA with an Omniscript ${ }^{\circledR}$ Reverse Transcription kit (Takara) with Oligo-dT primers (Takara) according to the manufacturer's instructions and used for RT-PCR. The target fragments were quantified by real-time PCR using a QuantiTectTMSYBR Green ${ }^{\circledR}$ PCR Kit (Roche) with 100 ng of the cDNA template. Each sample was tested in duplicate. The gene expression data were normalized to $\beta$-actin expression. The primers used correspond to the rat sequences shown in Table 1; primer design was done using Amplify software (TaKaRa, Nanjing, China). For each real-time PCR assay, the threshold cycle Ct was determined for each reaction. Ct values for each gene of interest were normalized to the housekeeping gene ( $\beta$ action); PCR amplification efficiencies were taken into account by amplifying various amounts of target cDNA for each reaction. The fold differences in mRNA expression of samples were relative to the internal control sample, which was included in all runs.

\section{Ion Concentration}

The concentrations of $\mathrm{Al}, \mathrm{Fe}, \mathrm{Cu}, \mathrm{Zn}$, and $\mathrm{Mg}$ in the liver, kidney, spleen, lung, heart, muscle, brain, and fat tissue were determined by inductively coupled plasma optical emission spectrometry (Optima 2100 DV; Perkin Elmer, Waltham, MA) using nitric acid-perchloric acid-based wet digestion. Approximately 200 $\mu \mathrm{l}$ or $0.5 \mathrm{~g}$ of each sample was digested with nitric acid (75\%) and perchloric acid (25\%) in a microwave digester (MDS- 81D; CEM Corp., Matthews, NC). We have used the same part of organ from the control and treated animals and accurately weighed.

\section{Statistical Analysis}

The data were expressed as mean \pm standard error of the mean (SEM) and were analyzed by one-way analysis of variance (ANOVA), followed by Dunnett's multiple comparison tests, which was performed with GraphPad Prismsoftware (GraphPad Software, San Diego, CA, USA). Differences were considered to be statistically significant when the $p$ level was less than 0.05 .

\section{RESULTS}

\section{Body and Organ Weights}

After administration of GLP, there was a significant distinction in rat body weight between the control group and the $500 \mathrm{mg} / \mathrm{kg}$ GLP group ( $p<0.05$, Table 2$)$. The body weight gain decreased significantly in $50 \mathrm{mg} / \mathrm{kg}$ and $500 \mathrm{mg} / \mathrm{kg}$ GLP treatment groups compared with the control group $(p<0.05)$. Significant difference was also observed in the average-day-gain and average daily feed intake in GLP treatment groups compared with the control group $(p<0.05)$. Both of the absolute organ weight or the relative organ weight for liver, spleen and kidney showed a significant decrease in the $500 \mathrm{mg} / \mathrm{kg}$ GLP group $(p<0.05$, Table 2), which suggested that GLP manifest toxicity principally toward growth and development at the studied dosages.

\section{Histopathologic Evaluation}

The liver and kidney histopathological changes were showed in Figure 1. The control rats showed hepatic lobules consisting of a central vein surrounded by radiating hepatocytes which were separated and did not exhibit any damage in the tissue (Figure 1A). By contrast, the liver sections of GLP-treated rats showed apoptosis of some hepatocyte, focal necrosis and mononuclear cell infiltration in liver tissue. Compared with the control group, after $5 \mathrm{mg} / \mathrm{kg}$ of GLP exposure, the rats showed mild periportal expansion and apoptosis of some hepatocyte (Figure 1B). In comparison, the livers of rats in the $50 \mathrm{mg} / \mathrm{kg}$ and $500 \mathrm{mg} / \mathrm{kg}$ GLP-treated groups demonstrated greater levels of structural disorder, apoptosis of some hepatocyte and monocyte infiltration (Figures 1C,D).

The HE staining of renal tissue in control rats demonstrated overall integrity of glomerulus surrounded by Bowman capsule 
TABLE 1 | Primers used for quantitative real-time PCR.

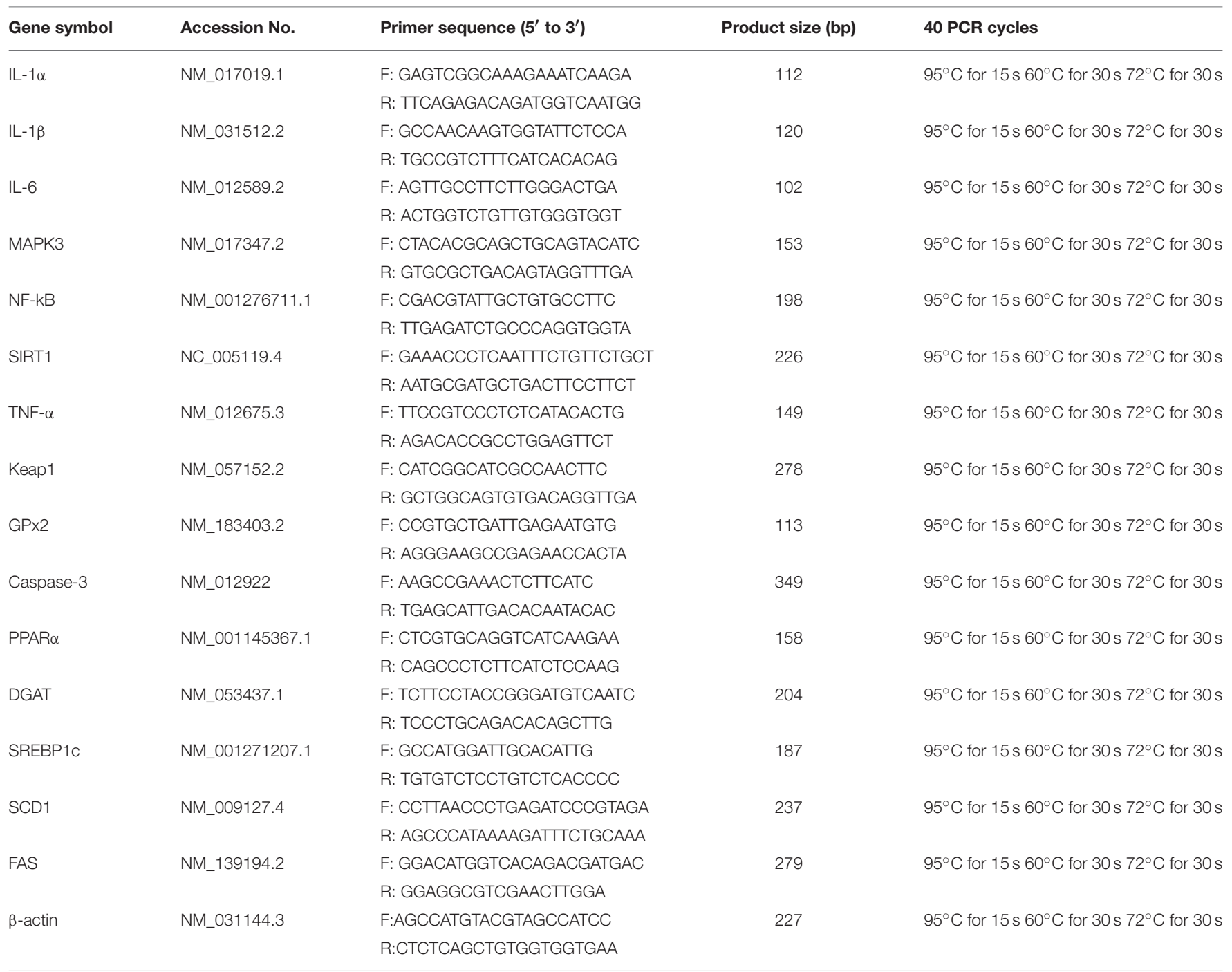

and convoluted tubules (Figure 1E). In comparison with control kidney, GLP administration induced markable histological changes, including proximal and distal tubular necrosis and glomerular toxicity (Figures $\mathbf{1 F}-\mathbf{H}$ ). And the histologic score of hepatic and renal damages was significantly increased in the both GLP-treated groups compared with the control group $(p<0.01)$ (Figures 1I,J).

\section{Assessment of Liver Function}

To confirm the damage of GLP to liver, the serum GOT and GPT levels, the main enzymes of liver function, were determined. The results showed that the levels of the GOT and GPT were increased in GLP-treated groups compared with the control rats. Furthermore, there was a significant increase in GOT and GPT levels with $500 \mathrm{mg} / \mathrm{kg}$ of glyphosate compared with the control group $(p<0.05)$ as shown in Figures 2A,B. These results showed that glyphosate can affect hepatic metabolism, causing oxidative damage to the hepatic tissue.

\section{Assessment of Enzyme Levels in the Serum to Test Oxidative Stress}

To determine whether the GLP could induce the oxidative stress in vivo, we first examined the SOD, CAT, GSH, and GSH-PX activities as well as the level of MDA in the serum. The results showed that SOD activity significantly decreased in the 500 $\mathrm{mg} / \mathrm{kg}$ GLP-treated group compared to the control $(p<0.05)$. The MDA content showed significant increase in the $50 \mathrm{mg} / \mathrm{kg}$ GLP-treated group compared with the control $(p<0.05)$, and significantly increased CAT activity than the control in the 500 $\mathrm{mg} / \mathrm{kg}$ GLP-treated group compared with the control $(p<0.05)$ (Table 3).

\section{Assessment of Enzyme Levels in the Liver and Kidney to Test Oxidative Stress}

Liver and kidney are two major organs that suffer from the oxidative stress, since GLP metabolism mainly occurs in the liver and the metabolites discharge in the kidney. After GLP 
TABLE 2 | Body weights and organ weights of rats treated with Glyphosate for 5 weeks.

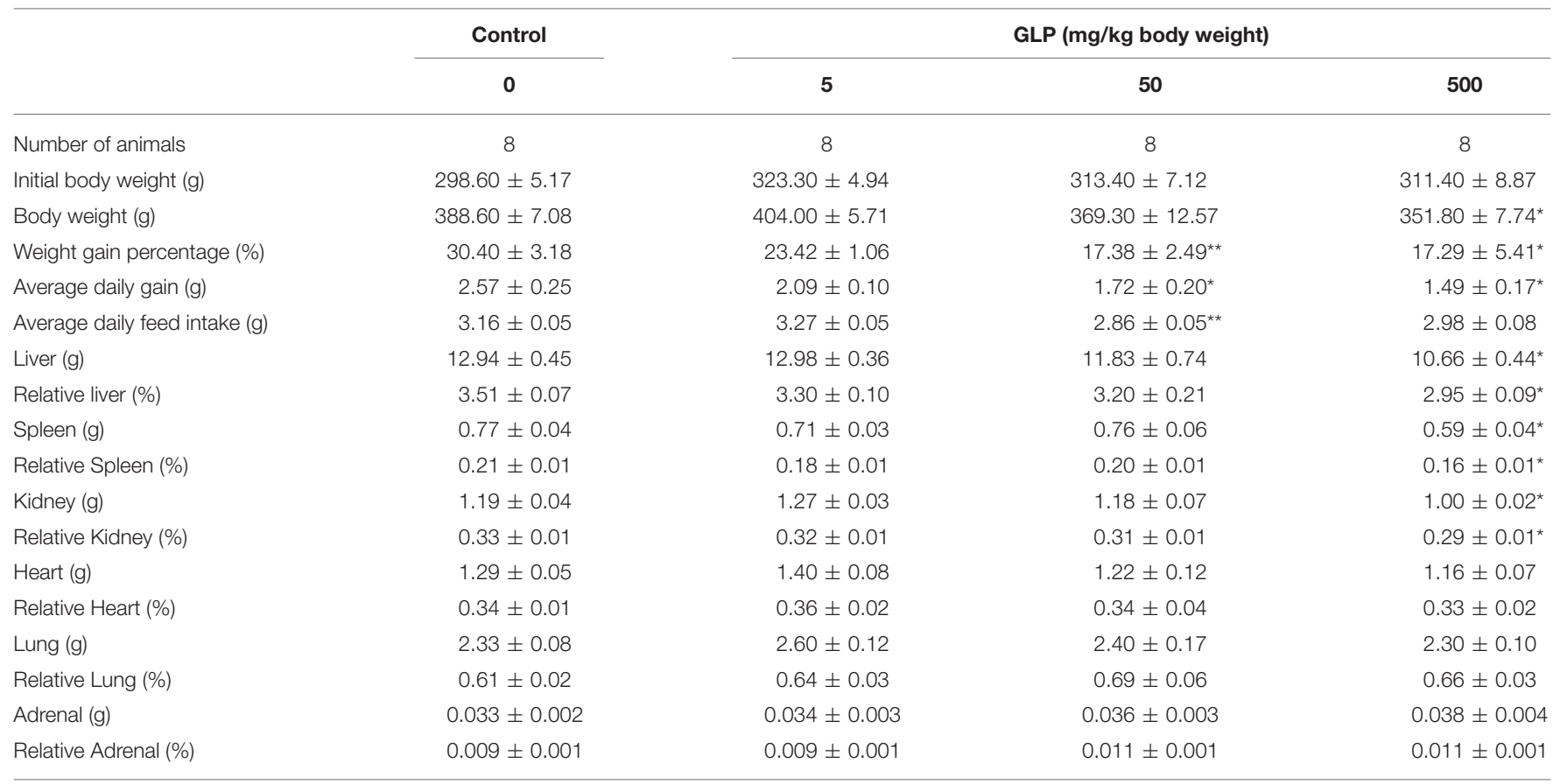

The values shown are the mean \pm SEM of 8 animals per group. Compared to control; ${ }^{*} p<0.05,{ }^{* *} p<0.01$.
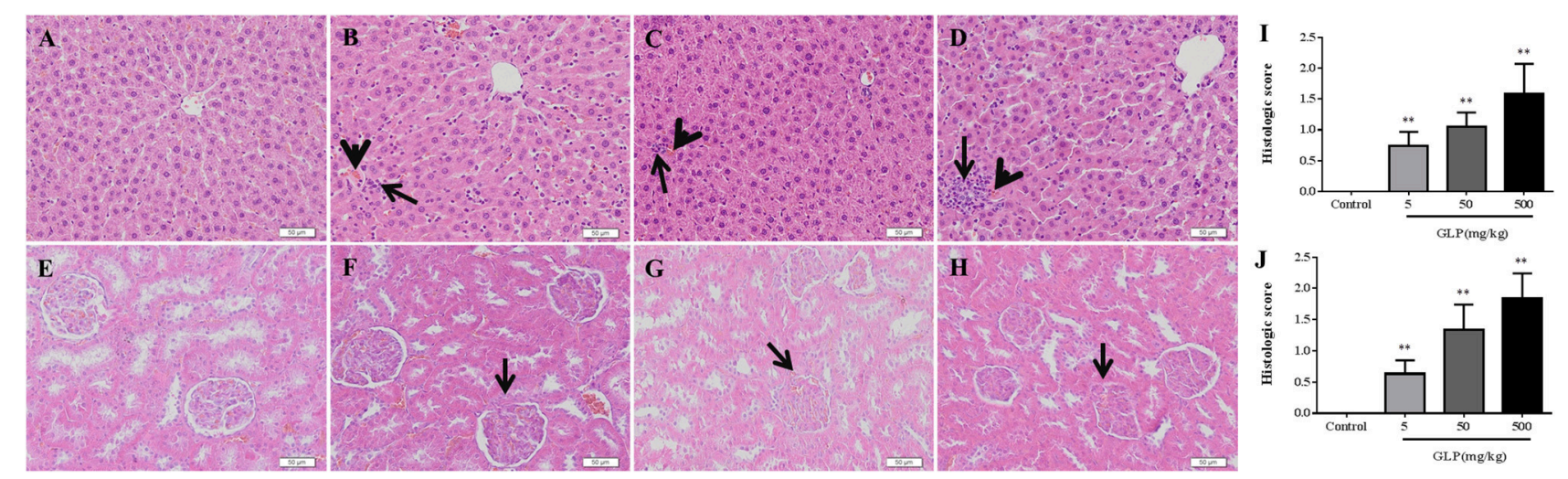

FIGURE 1 | Histopathological changes in the livers and kidneys of male rats following oral GLP administration through Hematoxylin and eosin staining. $200 \times$ magnification. (A) Normal liver section. Hepatic lobules consisting of a central vein surrounded by radiating hepatocytes which were separated; (B-D) GLP (5, 50, and $500 \mathrm{mg} / \mathrm{kg} /$ day) treated presenting periportal expansion, structural disorder, monocyte infiltration (arrows), and congestion (arrowheads). (E) Normal kidney section. No signs of kidney damage were observed in the kidney of controls; (F-H) GLP (5, 50, and $500 \mathrm{mg} / \mathrm{kg} /$ day) treated presenting proximal and distal tubular necrosis and glomerular toxicity (arrows). (I,J) The hepatic and renal damages histologic score evaluating. Data shown are mean \pm SEM of six liver sections in each group. Compared to control; ${ }^{* *} p<0.01$.

exposure, SOD activity in the $500 \mathrm{mg} / \mathrm{kg}$ GLP-treated group showed significant decrease in the liver compared with the control $(p<0.05)$. However, the level of $\mathrm{H}_{2} \mathrm{O}_{2}$ in the $500 \mathrm{mg} / \mathrm{kg}$ GLP-treated group significantly increased compared with the control group $(p<0.05)$ (Table 3).

Next, the activity of antioxidant enzymes in the kidney was examined. As shown in Table 3, the MDA content in the $5 \mathrm{mg} / \mathrm{kg}$ GLP-treated group showed significant increase compared with the control group $(p<0.01)$. The SOD and GSH-PX activities were significantly decreased in the $500 \mathrm{mg} / \mathrm{kg}$ GLP-treated groups compared with the control group $(p<0.05)$. And the GSH activity also showed significant decrease in the $50 \mathrm{mg} / \mathrm{kg}$ GLPtreated groups compared with the control group $(p<0.05)$. However, there was no difference for the $\mathrm{H}_{2} \mathrm{O}_{2}$ and CAT activities between the control and treatment groups (Table 3).

\section{Serum IL-1 $\beta$ and IL-6 Levels}

The concentrations of inflammatory mediators IL- $1 \beta$ and IL6 in serum were determined as shown in the Figure 3. The level of IL-1 $\beta$ has a significant increase in the $500 \mathrm{mg} / \mathrm{kg}$ GLP-treated group compared with the control rats $(p<0.05)$ (Figures 3A,B). 

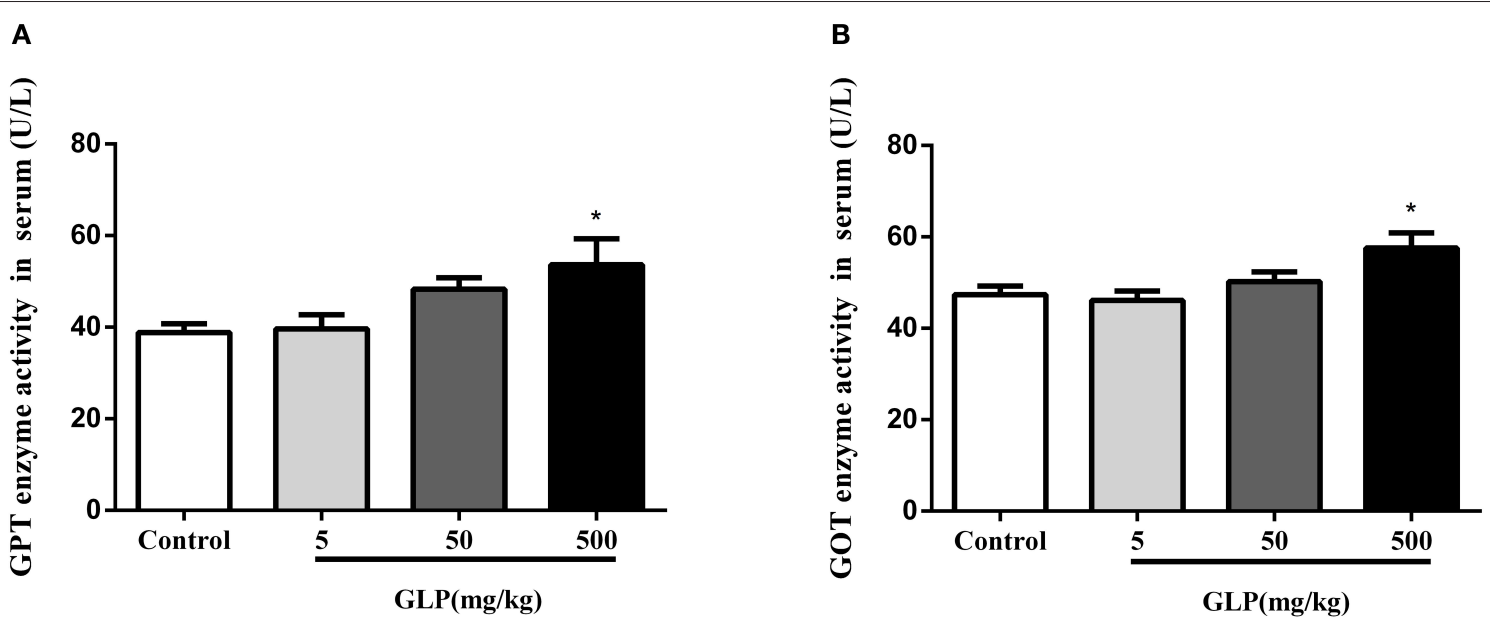

FIGURE 2 | Effect of GLP treatment on GPT (A) and GOT (B) enzyme activities in the serum. Data shown are mean \pm SEM of eight animals in each group. Compared to control; ${ }^{*} p<0.05$.

TABLE 3 | Effects of GLP on antioxidant enzyme activities and lipid peroxidation levels in serum, liver, and kidney of rats.

\begin{tabular}{|c|c|c|c|c|}
\hline & $\begin{array}{c}\text { Control } \\
0\end{array}$ & \multicolumn{3}{|c|}{ GLP (mg/kg body weight) } \\
\hline $\mathrm{SOD}(\mathrm{U} / \mathrm{mL})$ & $13.29 \pm 0.16$ & $13.01 \pm 0.58$ & $12.89 \pm 0.46$ & $11.30 \pm 0.28^{*}$ \\
\hline $\mathrm{MDA}(\mathrm{nmol} / \mathrm{mL})$ & $20.72 \pm 2.16$ & $22.06 \pm 2.03$ & $32.38 \pm 2.00^{\star \star}$ & $23.23 \pm 1.99$ \\
\hline $\mathrm{H}_{2} \mathrm{O}_{2}(\mathrm{nmol} / \mathrm{mL})$ & $113.50 \pm 10.05$ & $113.80 \pm 8.87$ & $117.50 \pm 6.63$ & $134.30 \pm 7.45$ \\
\hline GSH (mg/L) & $536.30 \pm 22.76$ & $431.90 \pm 46.45$ & $446.20 \pm 52.51$ & $423.40 \pm 47.15$ \\
\hline GSH-PX (U/L) & $378.20 \pm 37.47$ & $400.80 \pm 28.74$ & $429.00 \pm 37.64$ & $453.00 \pm 13.76$ \\
\hline \multicolumn{5}{|l|}{ LIVER } \\
\hline SOD (U/mgprot) & $49.77 \pm 2.06$ & $50.30 \pm 2.32$ & $47.08 \pm 1.49$ & $41.53 \pm 1.19^{\star}$ \\
\hline MDA (nmol/mgprot) & $1.93 \pm 0.06$ & $1.89 \pm 0.08$ & $1.86 \pm 0.08$ & $2.08 \pm 0.07$ \\
\hline $\mathrm{H}_{2} \mathrm{O}_{2}$ (nmol/mgprot) & $5.10 \pm 0.26$ & $5.42 \pm 0.27$ & $5.90 \pm 0.23$ & $6.27 \pm 0.14^{\star}$ \\
\hline \multicolumn{5}{|l|}{ KIDNEY } \\
\hline SOD (U/mgprot) & $97.67 \pm 4.51$ & $87.62 \pm 6.51$ & $75.10 \pm 4.17^{\star}$ & $73.06 \pm 3.31^{\star}$ \\
\hline MDA (nmol/mgprot) & $1.87 \pm 0.20$ & $3.91 \pm 0.25^{\star \star}$ & $3.015 \pm 0.49$ & $3.026 \pm 0.40$ \\
\hline $\mathrm{H}_{2} \mathrm{O}_{2}$ (nmol/mgprot) & $5.28 \pm 0.34$ & $6.03 \pm 0.63$ & $6.68 \pm 0.46$ & $5.58 \pm 0.37$ \\
\hline CAT (U/mgprot) & $764.20 \pm 38.35$ & $873.70 \pm 66.49$ & $865.90 \pm 83.28$ & $819.60 \pm 54.81$ \\
\hline GSH (mg/gprot) & $7.70 \pm 1.85$ & $4.31 \pm 0.45$ & $2.76 \pm 1.06^{\star}$ & $4.64 \pm 0.75$ \\
\hline GSH-PX (U/mgprot) & $480.00 \pm 19.96$ & $421.80 \pm 38.47$ & $342.20 \pm 40.60^{*}$ & $297.00 \pm 36.08^{\star \star}$ \\
\hline
\end{tabular}

The values shown are the mean \pm SEM of 8 animals per group. Compared to control; ${ }^{*} p<0.05,{ }^{* *} p<0.01$.

\section{Expression of mRNA Levels for Inflammation Related Genes in the Liver}

We investigated the effects of GLP involved in the inflammatory response in the liver tissue (Figure 4A). Hepatic $I L-1 \alpha$ and $I L$ $1 \beta$ mRNA expression were significantly increased after GLP exposure compared with the control group $(p<0.05)$; IL-6, $M A P K 3$, SIRT1, TNF- $\alpha, G P X 2$, and Caspase-3 mRNA expression were significantly increased in the $50 \mathrm{mg} / \mathrm{kg}$ and $500 \mathrm{mg} / \mathrm{kg}$ GLP-treated group compared with the control group $(p<0.05)$; $N F-\kappa B$ mRNA expression showed a significant increase in the $50 \mathrm{mg} / \mathrm{kg}$ GLP-treated group compared with the control group $(p<0.05)$; at the same time, we also observed a significant increase in Keap1 mRNA expression in $5 \mathrm{mg} / \mathrm{kg}$ GLP-treated group compared with the control group $(p<0.05)$. 

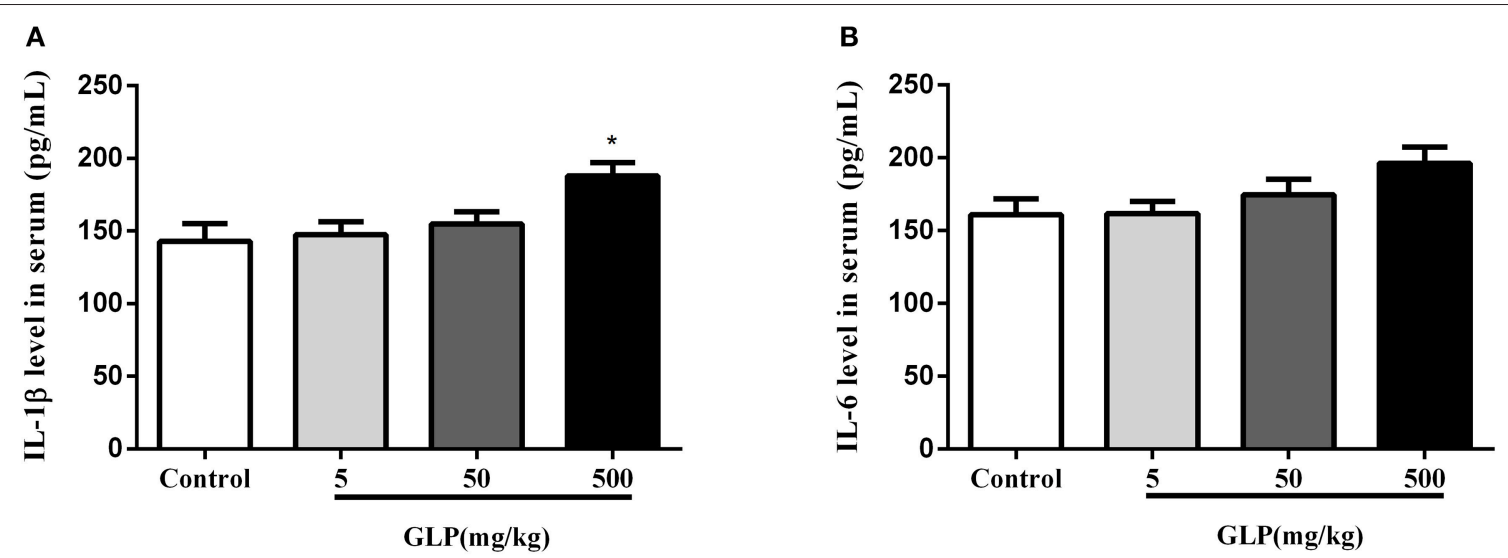

FIGURE 3 | The level of IL-1 $\beta$ (A) and IL-6 (B) in the serum was assayed by ELISA. Data shown are mean \pm SEM of eight animals in each group. Compared to control; ${ }^{*} p<0.05$.
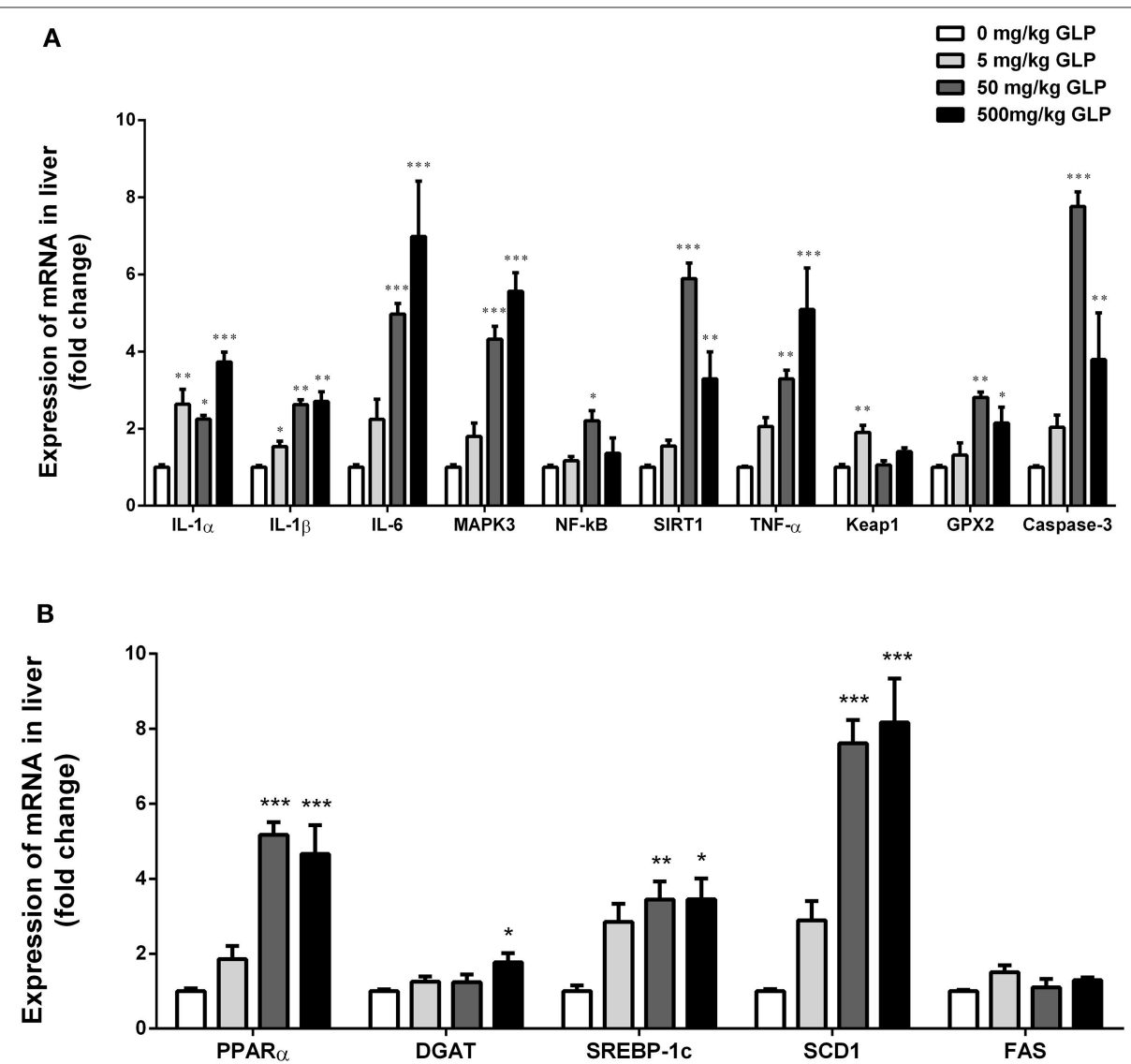

FIGURE 4 | Real-time RT-PCR analyses of IL-1 $\alpha$, IL-1 $\beta$, IL-6, MAPK3, NF-kB, SIRT1, TNF- $\alpha$, Keap1, GPX2, and Caspase-3 mRNA of liver (A). Real-time RT-PCR analyses of PPAR $\alpha$, DGAT, SREBP1c, SCD1, and FAS mRNA of liver (B). Data shown are mean \pm SEM of eight animals in each group. Compared to control; ${ }^{*} p<0.05,{ }^{* *} p<0.01$ and ${ }^{* * *} p<0.001$.

\section{Expression of mRNA Levels for Lipid}

\section{Metabolism Related Genes in the Liver}

Compared with the control group, PPAR $\alpha$, SREBP1c, and SCD1 mRNA expression were significantly increased in the $50 \mathrm{mg} / \mathrm{kg}$ and $500 \mathrm{mg} / \mathrm{kg}$ GLP treatment rats $(p<0.05)$; DGAT mRNA expression was significantly increased in the $500 \mathrm{mg} / \mathrm{kg}$ GLPtreated group compared with the control group $(p<0.05)$ (Figure 4B). 


\section{Concentrations of Ions in Liver, Kidney, Spleen, Heart, Lung, Brain, Muscle, and Fat}

Concentrations of $\mathrm{Al}, \mathrm{Fe}, \mathrm{Cu}, \mathrm{Zn}$, and $\mathrm{Mg}$ in the liver, kidney, spleen, lung, heart, muscle, brain and fat were presented in Tables 4, 5.

In liver, compared with the control group, $\mathrm{Al}$ and $\mathrm{Zn}$ concentrations were significantly increased in $50 \mathrm{mg} / \mathrm{kg}$ and $500 \mathrm{mg} / \mathrm{kg}$ GLP treatment group $(p<0.05)$; Fe concentration was significantly increased in $5 \mathrm{mg} / \mathrm{kg}$ GLP treatment group $(p<0.05)$ and $\mathrm{Mn}$ concentration was significantly increased in $500 \mathrm{mg} / \mathrm{kg}$ GLP treatment group ( $p<0.05)$; Mo concentration was significantly decreased in $5 \mathrm{mg} / \mathrm{kg}$ and $50 \mathrm{mg} / \mathrm{kg}$ GLP treatment group $(p<0.05)$ (Table 4).

In kidney, concentrations of Fe level was significantly increased in $50 \mathrm{mg} / \mathrm{kg}$ GLP treatment group compared with the control group $(p<0.05)$ (Table 4).

In spleen, $\mathrm{Fe}$ content showed significant increase in 50 $\mathrm{mg} / \mathrm{kg}$ GLP treatment group compared with the control group $(p<0.05)$ (Table 4).

In lung, $\mathrm{Al}$ concentration was significantly decreased in 5 $\mathrm{mg} / \mathrm{kg}$ and $50 \mathrm{mg} / \mathrm{kg}$ GLP treatment groups compared with the control group $(p<0.05)$; Fe concentration was significantly increased in $500 \mathrm{mg} / \mathrm{kg} \mathrm{GLP}$ treatment group compared with the control group $(p<0.05)$ (Table 5).
In brain, $\mathrm{Cu}$ content was significantly increased in 500 $\mathrm{mg} / \mathrm{kg}$ GLP treatment group compared with the control group $(p<0.05)$; $\mathrm{Mg}$ concentration significantly increased in $50 \mathrm{mg} / \mathrm{kg}$ and $500 \mathrm{mg} / \mathrm{kg}$ GLP treatment group compared with the control group $(p<0.05)$ (Table 5).

In muscle, $\mathrm{Al}$ concentration was significantly decreased in 500 $\mathrm{mg} / \mathrm{kg}$ GLP treatment group $(p<0.05)$ (Table 5).

In fat tissue, concentrations of $\mathrm{Cu}$ was significantly increased in $50 \mathrm{mg} / \mathrm{kg}$ and $500 \mathrm{mg} / \mathrm{kg}$ GLP treatment groups compared with the control group $(p<0.05)$ (Table 5).

\section{DISCUSSION}

The present study demonstrated that GLP had an adverse effect on the histomorphology, inflammation, oxidative stress, lipid metabolism and ion concentration in adult male rats, and then discussed the relationship between them. This is the first report about the effects of GLP exposure on $\mathrm{Al}, \mathrm{Fe}, \mathrm{Cu}, \mathrm{Zn}$, and $\mathrm{Mg}$ content in main tissues of rats. Also we firstly revealed the connection between dysregulation of ion content and liver injury in rats exposed to GLP.

The results of our study showed that exposure to GLP for 35 days led to a significant reduction in body weight, body weight gain, average daily gain, and liver, spleen and kidney

TABLE 4 | The concentrations of $\mathrm{Al}, \mathrm{Fe}, \mathrm{Cu}, \mathrm{Zn}$, and $\mathrm{Mg}$ in the liver, kidney, spleen, and heart of rats.

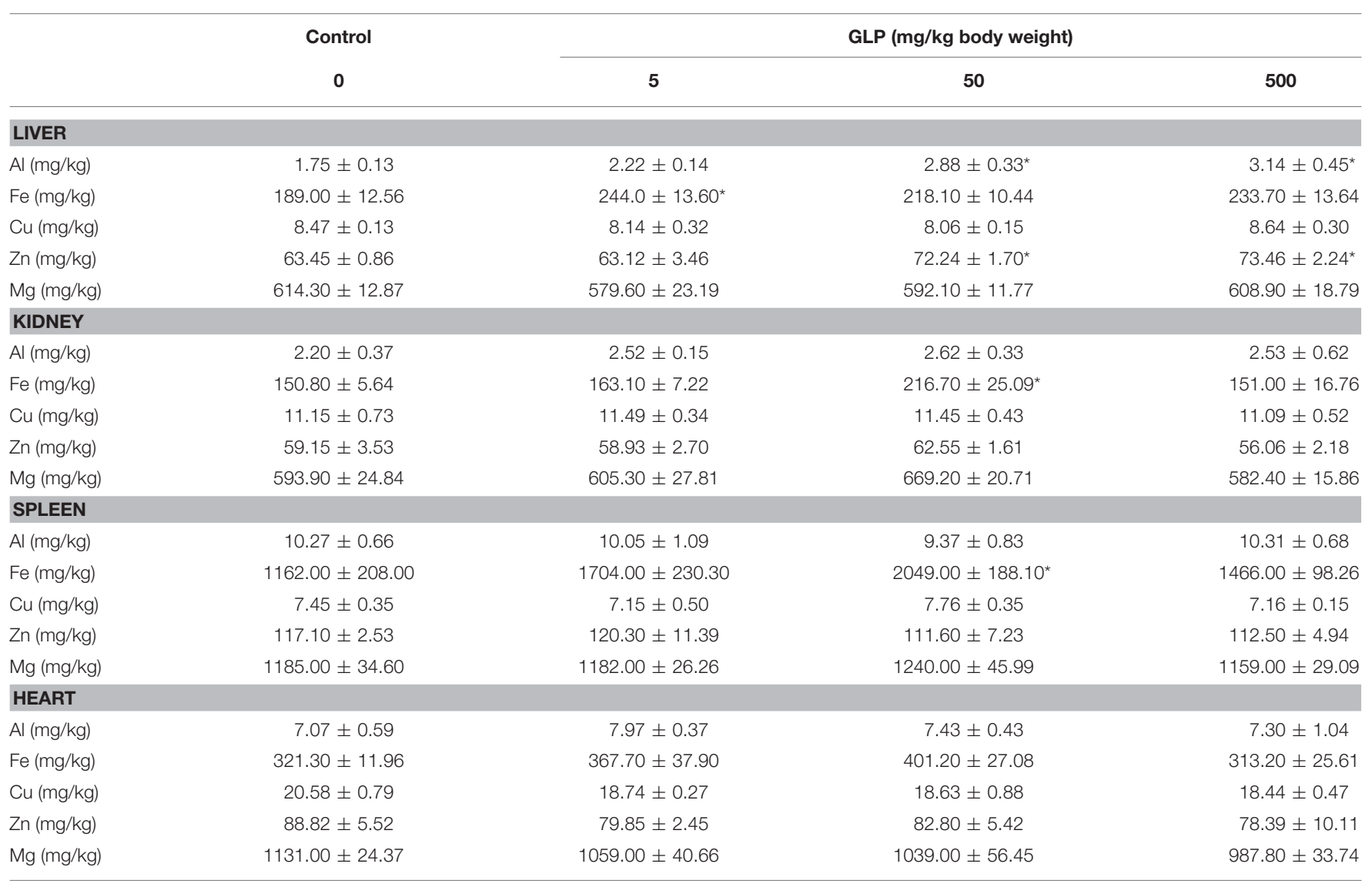

The values shown are the mean \pm SEM of 8 animals per group. Compared to control; ${ }^{*} p<0.05$. 
TABLE 5 | The concentrations of $\mathrm{Al}, \mathrm{Fe}, \mathrm{Cu}, \mathrm{Zn}$, and $\mathrm{Mg}$ in the lung, brain, muscle and fat of rats.

\begin{tabular}{|c|c|c|c|c|}
\hline & \multirow{2}{*}{$\begin{array}{c}\text { Control } \\
0\end{array}$} & \multicolumn{3}{|c|}{ GLP (mg/kg body weight) } \\
\hline & & 5 & 50 & 500 \\
\hline \multicolumn{5}{|l|}{ LUNG } \\
\hline $\mathrm{Al}(\mathrm{mg} / \mathrm{kg})$ & $26.55 \pm 1.14$ & $21.93 \pm 1.05^{\star}$ & $20.43 \pm 0.71^{\star \star}$ & $23.27 \pm 1.52$ \\
\hline $\mathrm{Fe}(\mathrm{mg} / \mathrm{kg})$ & $362.30 \pm 31.16$ & $446.00 \pm 32.30$ & $421.40 \pm 35.80$ & $647.30 \pm 74.77^{\star \star}$ \\
\hline $\mathrm{Cu}(\mathrm{mg} / \mathrm{kg})$ & $10.31 \pm 0.27$ & $10.13 \pm 0.46$ & $8.92 \pm 0.40$ & $9.94 \pm 0.83$ \\
\hline $\mathrm{Zn}(\mathrm{mg} / \mathrm{kg})$ & $211.00 \pm 14.07$ & $236.50 \pm 14.07$ & $187.10 \pm 6.99$ & $244.90 \pm 20.62$ \\
\hline $\mathrm{Mg}(\mathrm{mg} / \mathrm{kg})$ & $1133.00 \pm 17.40$ & $1114.00 \pm 18.28$ & $1045.00 \pm 21.90$ & $1016.00 \pm 63.47$ \\
\hline \multicolumn{5}{|l|}{ BRAIN } \\
\hline $\mathrm{Al}(\mathrm{mg} / \mathrm{kg})$ & $4.74 \pm 1.16$ & $5.08 \pm 0.73$ & $5.38 \pm 0.55$ & $4.17 \pm 0.24$ \\
\hline $\mathrm{Fe}(\mathrm{mg} / \mathrm{kg})$ & $40.79 \pm 0.59$ & $50.21 \pm 6.04$ & $47.38 \pm 2.20$ & $53.01 \pm 1.49$ \\
\hline $\mathrm{Cu}(\mathrm{mg} / \mathrm{kg})$ & $4.08 \pm 0.04$ & $4.50 \pm 0.06$ & $5.35 \pm 0.59$ & $5.70 \pm 0.24^{\star}$ \\
\hline Zn (mg/kg) & $35.59 \pm 1.36$ & $37.82 \pm 1.08$ & $51.28 \pm 8.54$ & $39.62 \pm 1.71$ \\
\hline $\mathrm{Mg}(\mathrm{mg} / \mathrm{kg})$ & $357.60 \pm 8.83$ & $357.90 \pm 12.81$ & $415.40 \pm 3.05^{\star \star}$ & $416.50 \pm 6.58^{\star \star}$ \\
\hline \multicolumn{5}{|l|}{ MUSCLE } \\
\hline $\mathrm{Al}(\mathrm{mg} / \mathrm{kg})$ & $7.52 \pm 0.55$ & $7.54 \pm 0.44$ & $6.56 \pm 0.54$ & $5.48 \pm 0.20^{\star}$ \\
\hline $\mathrm{Fe}(\mathrm{mg} / \mathrm{kg})$ & $52.76 \pm 2.45$ & $57.89 \pm 6.47$ & $54.62 \pm 4.48$ & $72.62 \pm 22.37$ \\
\hline $\mathrm{Cu}(\mathrm{mg} / \mathrm{kg})$ & $3.68 \pm 0.27$ & $3.47 \pm 0.24$ & $3.51 \pm 0.35$ & $3.46 \pm 0.15$ \\
\hline Zn (mg/kg) & $53.05 \pm 4.89$ & $53.28 \pm 2.37$ & $55.79 \pm 3.83$ & $58.50 \pm 6.08$ \\
\hline $\mathrm{Mg}(\mathrm{mg} / \mathrm{kg})$ & $1313.00 \pm 14.13$ & $1197.00 \pm 26.59$ & $1262.00 \pm 33.24$ & $1223.00 \pm 55.23$ \\
\hline \multicolumn{5}{|l|}{ FAT } \\
\hline Al (mg/kg) & $3.22 \pm 0.29$ & $2.37 \pm 0.57$ & $4.09 \pm 0.40$ & $3.23 \pm 0.15$ \\
\hline $\mathrm{Fe}(\mathrm{mg} / \mathrm{kg})$ & $11.16 \pm 1.33$ & $10.92 \pm 4.01$ & $16.44 \pm 2.33$ & $14.41 \pm 1.82$ \\
\hline $\mathrm{Cu}(\mathrm{mg} / \mathrm{kg})$ & $0.29 \pm 0.05$ & $0.35 \pm 0.10$ & $0.53 \pm 0.03^{\star}$ & $0.61 \pm 0.04^{\star *}$ \\
\hline Zn (mg/kg) & $5.65 \pm 0.81$ & $5.35 \pm 0.53$ & $6.36 \pm 0.70$ & $6.27 \pm 1.02$ \\
\hline $\mathrm{Mg}(\mathrm{mg} / \mathrm{kg})$ & $25.49 \pm 1.25$ & $25.99 \pm 2.60$ & $33.41 \pm 1.96$ & $33.57 \pm 4.12$ \\
\hline
\end{tabular}

The values shown are the mean \pm SEM of 8 animals per group. Compared to control; ${ }^{*} p<0.05,{ }^{* *} p<0.01$.

coefficient. These results suggested that treated with GLP in male rats for 35 days could affect the growth performance of rats. In addition, our results also showed that exposure to GLP for 35 days caused significant hyperemia, cellular degeneration and necrosis accompanied inflammatory cell infiltration, renal tubular damage and glomerular filtration impairment in rats' hepatic and kidney cells, accompanied by significant increases in GPT and GOT levels. Transaminases are important enzymes and critical enzymes in the biological processes. GPT and GOT levels increased in serum can be a sign of liver damage and disruption of normal liver function (El-Demerdash et al., 2001; Celik and Suzek, 2008). Results showed that GLP caused damage in liver morphology and function.

Oxidative stress refers to the oxidation and anti-oxidation imbalance in vivo (Hou et al., 2013). Some studies reported that GLP is an organophosphate herbicide and can induce to oxidative stress and/or an impairment of the antioxidant defensive mechanisms (Larsen et al., 2012). Animals possess an antioxidant defense mechanism composed of enzymes including T-SOD and GPx, as well as non-enzymatic antioxidants including non-protein thiols, especially GSH. When the defenses of the organism are insufficient for neutralizing the ROS, oxidative damage can occur, and one of the most serious types of which is membrane lipid peroxidation (Ahmad et al., 2004). Liver is the major detoxification organ exposed to food or drinks contaminants (Gasnier et al., 2009). GLP-based herbicide has been demonstrated to damage carp or rat hepatocytes at low levels (Szarek et al., 2000; Malatesta et al., 2008).

MDA, the stable metabolite of lipid peroxidation (LPO) products, is a biomarker of LPO (Sun et al., 2001), and is presented as the total level of LPO products (Drewa et al., 2002). MDA can be produced by ozone, which reacts rapidly with cellular structures and generates hydrogen peroxide (Ajamieh et al., 2004). Hepatic SOD activity also can suggest the extent of liver damage (Li et al., 2013). CAT catalyzing the breakdown of $\mathrm{H}_{2} \mathrm{O}_{2}$ into $\mathrm{O}_{2}$ and $\mathrm{H}_{2} \mathrm{O}$ and catalyzing the oxidation of electron donors (Hou et al., 2013). In addition, GSH provide the major defense against oxidative stress induced cellular damage (Beuret et al., 2005; Ozden and Alpertunga, 2010). In the present study, our results showed that SOD activity significantly decreased in the serum, liver and kidney of the GLP-treated rats compared with the control group. MDA content showed significant increase in the serum and kidney of the GLP-treated rats. At the same time, CAT activity was also significantly increased in the serum of the GLP-treated rats compared with the control group. In addition, $\mathrm{H}_{2} \mathrm{O}_{2}$ increased in the liver tissue, suggesting $t$ that rats were under the oxidant stress. Taken together, the data demonstrated that GLP could result in liver and kidney damage, 
the decreased SOD activity in the serum and tissue, and the increased MDA level in the serum, indicative of oxidative stress. On the other side, we have also tested the inflammatory Cytokines level in serum, our results showed that the level of IL$1 \beta$ has a significant increase in the $500 \mathrm{mg} / \mathrm{kg}$ GLP-treated group compared with the control rats. Thus, we investigate whether the oxidative stress state of organism has a certain relationship with the inflammation related genes.

Inflammation, manifested as macrophage infiltration of adipose tissue, endoplasmic reticulum stress and oxidative stress (Trayhurn and Wood, 2004). In a few cases, steatosis causes apoptosis, necrosis, generation of oxidative stress and inflammation (Marchesini et al., 2008). Animal models of nonalcoholic fatty liver disease have also suggested a possible role of free fatty acids, not triglycerides, in the hepatocytes as factors promoting hepatocellular injury (Yamaguchi et al., 2007). GLP induced inflammation, which was found to be associated with induction of IL-33, which is known to induce TNF- $\alpha$, IFN$\gamma$, and IL-13 upon antigen challenge followed by activation and recruitment of inflammatory cells in the airways (Kumar et al., 2014). In this study, the mRNA expression of $I L-1 \alpha, I L-1 \beta, I L$ 6, MAPK3, NF- $-B$, SIRT1, TNF- $\alpha$, Keap1, GPX2 and Caspase-3 were all increased in GLP treatment group compared with the liver tissue of control rats. Meanwhile, PPAR $\alpha$, SREBP1c, DGAT, and SCD1 mRNA expressions were significantly increased in GLP treatment rats. It showed that GLP induced liver toxicity is mediated by inflammation, oxidative stress and lipid related pathways. In addition, in the present study, we only focus on changes in inflammatory markers and lipid metabolite levels in the liver, possible changes in kidneys will continue to be verified in future experiments.

Additionally, previous studies also indicated that GLP is bound to the soil constituent $\mathrm{Fe}, \mathrm{Al}$ amorphous hydroxides and ferric oxides (Piccolo et al., 1994; Day et al., 1997). GLP negatively impact human health, and interference with cytochrome P450 (CYP) enzymes, which play many important roles in the body, meanwhile, GLP chelation of minerals, such as iron and cobalt (Samsel and Seneff, 2013). Al accumulation resulted in obvious damage to hepatic cells, including liver central venous hyperemia, lipid accumulation, and lymphocyte infiltration (Bogdanović et al., 2008; Türkez et al., 2010). Fe is an essential nutritional mineral for all life forms, both of Fe deficiency and excess in Fe also leads to oxidative DNA damage (Ames, 2001). Becaria reported that $\mathrm{Al}$ augmented oxidative stress injuries induced by Fe (Becaria et al., 2002). Zn has a relationship with many enzymes in the body (Powell, 2000; Ozturk et al., 2003; Ozdemir and Inanc, 2005). One study has shown that

\section{REFERENCES}

Aebi, H. (1984). Catalase in vitro. Methods Enzymol. 105, 121-126. doi: 10.1016/S0076-6879(84)05016-3

Ahmad, I., Pacheco, M., and Santos, M. (2004). Enzymatic and nonenzymatic antioxidants as an adaptation to phagocyte-induced damage in Anguilla anguilla L. following in situ harbor water exposure. Ecotox. Environ. Saf. 57, 290-302. doi: 10.1016/S0147-6513(03)00080-0
Zn deficiency increases lipid peroxidation in various rat tissues (Ozdemir and Inanc, 2005). Mg plays a pivotal role as an enzyme cofactor in biosynthesis of proteins and mineral administration. It is indispensable to osteogenesis and mineralization of bones (Rahnama and Marciniak, 2002). Subacute Mg deficiency can cause lymphopoietic neoplasms in young rats (Ilicin, 1971). Mg, $\mathrm{Zn}$, and $\mathrm{Cu}$ are the cofactors of SOD. $\mathrm{Fe}$ and $\mathrm{Cu}$ overload could cause oxidative stress damage to rats' kidney and liver (Ozcelik et al., 2003; Bishu and Agarwal, 2006). This study results showed that the concentration of $\mathrm{Al}, \mathrm{Fe}$ and $\mathrm{Zn}$ were significantly increased in GLP-treated rats' liver. Concentrations of Fe were also increased in the kidney, spleen, and lung tissue in GLP-treated rats. Al concentration was decreased in the muscle tissue of GLP-treated rats. In brain and fat tissue, $\mathrm{Cu}$ and $\mathrm{Mg}$ concentration were increased in GLP-treated rats. However, there showed no dose-dependent effect of GLP was found. Combined, these results suggested that GLP induced the ion-imbalance of $\mathrm{Al}, \mathrm{Fe}, \mathrm{Mg}, \mathrm{Cu}$, and $\mathrm{Zn}$, which will make damage to hepatic cells and liver dysfunction, and the role of ion-imbalance in renal and other organs will continue to be verified in future experiments.

In summary, current study demonstrated that GLP causes obvious damage to rat liver, kidney and caused ion-imbalance in main tissue of rats, and the ion-imbalance is no dose-dependent effect of GLP was found. It may be due to the too large dose range we used in the study of the GLP. Ion imbalance-related oxidative stress may be involved in the mechanism of chronic liver injury caused by GLP. Simultaneously, GLP-induced ion imbalance and oxidative stress may also affect kidney damage. Therefore, the role of ion-imbalance in renal and other organs and its mechanism must be further confirmed by systematic experiments in the future.

\section{AUTHOR CONTRIBUTIONS}

JT, PH, YL, T-TW-S, and CL: Performed experiments and interpreted data; CL: Designed the study and provided funding; JT: Wrote the manuscript. All authors read and approved the final version of the manuscript.

\section{ACKNOWLEDGMENTS}

This work was supported by the National Key Research and Development Program of China (2016YFD0500505). National Nature Science Foundation of China (No. 31772648) and Graduate research and innovation projects of Jiangsu Province (KYLX15_0554). 
Aust, S. D., Morehouse, L. A., and Thomas, C. E. (1985). Role of metals in oxygen radical reactions. J. Free Radic. Biol. Med. 1, 3-25. doi: 10.1016/0748-5514(85)90025-X

Ayoola, S. O. (2008). Toxicity of glyphosate herbicide on Nile tilapia (Oreochromis niloticus) juvenile. Afr. J. Agr Res. 3, 825-834.

Becaria, A., Campbell, A., and Bondy, S. (2002). Aluminum as a toxicant. Toxicol. Ind. Health. 18, 309-320. doi: 10.1191/0748233702th157oa

Bellaloui, N., Reddy, K. N., Zablotowicz, R. M., Abbas, H. K., and Abel, C. A. (2009). Effects of glyphosate application on seed iron and root ferric (III) reductase in soybean cultivars. J. Agr. Food Chem. 57, 9569-9574. doi: 10.1021/jf902175y

Benedetti, A. L., Vituri Cde, L., Trentin, A. G., Domingues, M. A., and Alvarez-Silva, M. (2004). The effects of sub-chronic exposure of Wistar rats to the herbicide Glyphosate-Biocarb. Toxicol. Lett. 153, 227-232. doi: 10.1016/j.toxlet.2004.04.008

Beuret, C. J., Zirulnik, F., and Giménez, M. S. (2005). Effect of the herbicide glyphosate on liver lipoperoxidation in pregnant rats and their fetuses. Reprod. Toxicol. 19, 501-504. doi: 10.1016/j.reprotox.2004.09.009

Bishu, K., and Agarwal, R. (2006). Acute injury with intravenous iron and concerns regarding long-term safety. Clin. J. Am. Soc. Nephro. 1, S19-S23. doi: 10.2215/CJN.01420406

Bogdanović, M., Janeva, A. B., and Bulat, P. (2008). Histopathological changes in rat liver after a single high dose of aluminium. Arh. Hig. Rada Toksikol. 59, 97-101. doi: 10.2478/10004-1254-59-2008-1859

Cattani, D., de Liz Oliveira Cavalli, V. L., Heinz Rieg, C. E., Domingues, J. T., Dal-Cim, T., Tasca, C. I., et al. (2014). Mechanisms underlying the neurotoxicity induced by glyphosate-based herbicide in immature rat hippocampus: involvement of glutamate excitotoxicity. Toxicology 320, 34-45. doi: 10.1016/j.tox.2014.03.001

Celik, I., and Suzek, H. (2008). The hematological effects of methyl parathion in rats. J. Hazard. Mater. 153, 1117-1121. doi: 10.1016/j.jhazmat.2007.09.067

Coutinho, C., Tanimoto, S., Galli, A., Gustavo, S., Takayama, M., Raquel, B., et al. (2005). Pesticides: action mechanism, degradation and toxicity. Pesticidas 15, 65-72.

Crisponi, G., Fanni, D., Gerosa, C., Nemolato, S., Nurchi, V. M., CrespoAlonso, M., et al. (2013). The meaning of aluminium exposure on human health and aluminium-related diseases. Biomol. Concepts 4, 77-87. doi: 10.1515/bmc-2012-0045

Day, G., Hart, B., McKelvie, I., and Beckett, R. (1997). Influence of natural organic matter on the sorption of biocides onto goethite, II. Glyphosate. Environ. Technol. 18, 781-794. doi: 10.1080/09593331808616597

Draper, H. H., and Hadley, M. (1990). Malondialdehyde determination as index of lipid Peroxidation. Methods Enzymol. 186, 421-431. doi: 10.1016/0076-6879(90)86135-I

Drewa, G., Krzyzynska-Malinowska, E., Wozniak, A., Protas-Drozd, F., MilaKierzenkowska, C., Rozwodowska, M., et al. (2002). Activity of superoxide dismutase and catalase and the level of lipid peroxidation products reactive with TBA in patients with psoriasis. Med. Sci. Monit. 8, BR338-BR343.

Eker, S., Ozturk, L., Yazici, A., Erenoglu, B., Romheld, V., and Cakmak, I. (2006). Foliar-applied glyphosate substantially reduced uptake and transport of iron and manganese in sunfl ower (Helianthus annuus L.) plants. J. Agric. Food Chem. 54, 10019-10025. doi: 10.1021/jf0625196

El-Demerdash, F., Yousef, M., and Elagamy, E. (2001). Influence of paraquat, glyphosate, and cadmium on the activity of some serum enzymes and protein electrophoretic behavior (in vitro). J. Environ. Sci. Health B 36, 29-42. doi: 10.1081/PFC-100000914

El-Shenawy, N. S. (2009). Oxidative stress responses of rats exposed to Roundup and its active ingredient glyphosate. Environ. Toxicol. Pharmacol. 28, 379-385. doi: 10.1016/j.etap.2009.06.001

Elstner, E. F., and Heupel, A. (1976). Inhibition of nitrite formation from hydroxylammoniumchloride: a simple assay for superoxide dismutase. Anal. Biochem. 70, 616-620. doi: 10.1016/0003-2697(76)90488-7

Frisvold, G. B., Hurley, T. M., and Mitchell, P. D. (2010). Overview: herbicide resistant crops-diffusion, benefits, pricing and resistance management. AgBioForum 12, 244-248.

Gasnier, C., Dumont, C., Benachour, N., Clair, E., Chagnon, M.-C., and Séralini, G.-E. (2009). Glyphosate-based herbicides are toxic and endocrine disruptors in human cell lines. Toxicology 262, 184-191. doi: 10.1016/j.tox.2009.06.006
Geyikoglu, F., Turkez, H., Bakir, T. O., and Cicek, M. (2013). The genotoxic, hepatotoxic, nephrotoxic, haematotoxic and histopathological effects in rats after aluminium chronic intoxication. Toxicol. Ind. Health 29, 780-791. doi: 10.1177/0748233712440140

Hou, Y. J., Zhao, Y. Y., Xiong, B., Cui, X. S., Kim, N. H., Xu, Y. X., et al. (2013). Mycotoxin-containing diet causes oxidative stress in the mouse. PLoS ONE 8:e60374. doi: 10.1371/journal.pone.0060374

Ilicin, G. (1971). Serum copper and magnesium levels in leukaemia and malignant lymphoma. Lancet 2, 1036-1037. doi: 10.1016/S0140-6736(71)90 353-9

Ishak, K., Baptista, A., Bianchi, L., Callea, F., De Groote, J., Gudat, F., et al. (1995). Histological grading and staging of chronic hepatitis. J. Hepatol. 22, 696-699. doi: $10.1016 / 0168-8278(95) 80226-6$

Klopfleisch, R. (2013). Multiparametric and semiquantitative scoring systems for the evaluation of mouse model histopathology-a systematic review. BMC Vet. Res. 9:123. doi: 10.1186/1746-6148-9-123

Krewski, D., Yokel, R. A., Nieboer, E., Borchelt, D., Cohen, J., Harry, J., et al. (2007). Human health risk assessment for aluminium, aluminium oxide, and aluminium hydroxide. J. Environ Sci. Health B 10, 1-269. doi: 10.1080/10937400701597766

Kumar, S., Khodoun, M., Kettleson, E. M., McKnight, C., Reponen, T., Grinshpun, S. A., et al. (2014). Glyphosate-rich air samples induce IL-33, TSLP and generate IL-13 dependent airway inflammation. Toxicology 325, 42-51. doi: 10.1016/j.tox.2014.08.008

Kumar, V., and Gill, K. D. (2009). Aluminium neurotoxicity: neurobehavioural and oxidative aspects. Arch. Toxicol. 83, 965-978. doi: 10.1007/s00204-0090455-6

Larini, L. (1999). In Toxicologia dos Praguicidas, ed Manole, 178-179.

Larsen, K., Najle, R., Lifschitz, A., and Virkel, G. (2012). Effects of sublethal exposure of rats to the herbicide glyphosate in drinking water: glutathione transferase enzyme activities, levels of reduced glutathione and lipid peroxidation in liver, kidneys and small intestine. Environ. Toxicol. Pharmacol. 34, 811-818. doi: 10.1016/j.etap.2012.09.005

Li, C.-M., Li, L., Bai, J.-Y., Wu, J., Huang, S., and Wang, G.-L. (2013). Correlation between heat shock protein 32 and chronic heatinduced liver injury in developing mice. J. Therm. Biol. 38, 513-519. doi: 10.1016/j.jtherbio.2013.08.006

Li, Y., Yang, L., Wang, W., Li, H., Lv, J., and Zou, X. (2011). Trace element concentrations in hair of healthy Chinese centenarians. Sci. Total Environ. 409, 1385-1390. doi: 10.1016/j.scitotenv.2011.01.017

Malatesta, M., Perdoni, F., Santin, G., Battistelli, S., Muller, S., and Biggiogera, M. (2008). Hepatoma tissue culture (HTC) cells as a model for investigating the effects of low concentrations of herbicide on cell structure and function. Toxicol. In Vitro 22, 1853-1860. doi: 10.1016/j.tiv.2008.09.006

Marchesini, G., Moscatiello, S., Di Domizio, S., and Forlani, G. (2008). Obesity-associated liver disease. J. Clin Endocr. Metab. 93, S74-S80. doi: 10.1210/jc.2008-1399

Modesto, K. A., and Martinez, C. B. (2010). Roundup ${ }^{\circledR}$ causes oxidative stress in liver and inhibits acetylcholinesterase in muscle and brain of the fish Prochilodus lineatus. Chemosphere 78, 294-299. doi: 10.1016/j.chemosphere.2009.10.047

Oteiza, P. I., Adonaylo, V. N., and Keen, C. L. (1999). Cadmium-induced testes oxidative damage in rats can be influenced by dietary zinc intake. Toxicology 137, 13-22. doi: 10.1016/S0300-483X(99)00067-0

Ozcelik, D., Ozaras, R., Gurel, Z., Uzun, H., and Aydin, S. (2003). Coppermediated oxidative stress in rat liver. Biol. Trace Elem. Res. 96, 209-215. doi: 10.1385/BTER:96:1-3:209

Ozdemir, G., and Inanc, F. (2005). Zinc may protect remote ocular injury caused by intestinal ischemia reperfusion in rats. Tohoku J. Exp. Med. 206, 247-251. doi: 10.1620/tjem.206.247

Ozden, S., and Alpertunga, B. (2010). Effects of methiocarb on lipid peroxidation and glutathione level in rat tissues. Drug Chem. Toxicol. 33, 50-54. doi: 10.3109/01480540903130708

Ozturk, A., Baltaci, A. K., Mogulkoc, R., Oztekin, E., Sivrikaya, A., Kurtoglu, E., et al. (2003). Effects of zinc deficiency and supplementation on malondialdehyde and glutathione levels in blood and tissues of rats performing swimming exercise. Biol. Trace Elem. Res. 94, 157-166. doi: 10.1385/BTER:94:2:157 
Piccolo, A., Celano, G., Arienzo, M., and Mirabella, A. (1994). Adsorption and desorption of glyphosate in some European soils. J. Environ. Sci. Health B 29, 1105-1115. doi: 10.1080/03601239409372918

Powell, S. R. (2000). The antioxidant properties of zinc. J. Nutr. 130 (Suppl. 5S), 1447S-1454S.

Rahnama, M., and Marciniak, A. (2002). Influence of estrogen deficiency on the level of magnesium in rat mandible and teeth. Bull Vet. Inst. Pulawy 46, 267-272.

Reitman, S., and Frankel, S. (1957). A colorimetric method for the determination of serum glutamic oxalacetic and glutamic pyruvic transaminases. Am. J. Clin Pathol. 28, 56-63. doi: 10.1093/ajcp/28.1.56

Samsel, A., and Seneff, S. (2013). Glyphosate, pathways to modern diseases II: celiac sprue and gluten intolerance. Interdiscip. Toxicol. 6, 159-184. doi: 10.2478/intox-2013-0026

Sedlak, J., and Lindsay, R. H. (1968). Estimation of total, protein-bound, and nonprotein sulfhydryl groups in tissue with Ellman's reagent. Anal. Biochem. 25, 192-205. doi: 10.1016/0003-2697(68)90092-4

Sun, F., Hamagawa, E., Tsutsui, C., Ono, Y., Ogiri, Y., and Kojo, S. (2001). Evaluation of oxidative stress during apoptosis and necrosis caused by carbon tetrachloride in rat liver. Biochim. Biophys. Acta 1535, 186-191. doi: 10.1016/S0925-4439(00)00098-3

Szarek, J., Siwicki, A., Andrzejewska, A., Terech-Majewska, E., and Banaszkiewicz, T. (2000). Effects of the herbicide Roundup ${ }^{\mathrm{TM}}$ on the ultrastructural pattern of hepatocytes in carp (Cyprinus carpio). Mar. Environ. Res. 50, 263-266. doi: 10.1016/S0141-1136(00)00088-X

Temple, W. A., and Smith, N. A. (1992). Glyphosate herbicide poisoning experience in New Zealand. New Z. Med. J. 105, $173-174$.
Trayhurn, P., and Wood, I. S. (2004). Adipokines: inflammation and the pleiotropic role of white adipose tissue. Br. J. Nutr. 92, 347-355. doi: 10.1079/BJN20041213

Türkez, H., Yousef, M. I., and Geyikoglu, F. (2010). Propolis prevents aluminiuminduced genetic and hepatic damages in rat liver. Food Chem. Toxicol. 48, 2741-2746. doi: 10.1016/j.fct.2010.06.049

Williams, G. M., Kroes, R., and Munro, I. C. (2000). Safety evaluation and risk assessment of the herbicide Roundup and its active ingredient, glyphosate, for humans. Regul. Toxicol. Phar. 31, 117-165. doi: 10.1006/rtph.1999.1371

Yamaguchi, K., Yang, L., McCall, S., Huang, J., Yu, X. X., Pandey, S. K., et al. (2007). Inhibiting triglyceride synthesis improves hepatic steatosis but exacerbates liver damage and fibrosis in obese mice with nonalcoholic steatohepatitis. Hepatology 45, 1366-1374. doi: 10.1002/hep.21655

Zheng, Z., Schmidt-Ott, K. M., Chua, S., Foster, K. A., Frankel, R. Z., Pavlidis, P., et al. (2005). A Mendelian locus on chromosome 16 determines susceptibility to doxorubicin nephropathy in the mouse. Proc. Natl. Acad. Sci. U.S.A. 102, 2502-2507. doi: 10.1073/pnas.0409786102

Conflict of Interest Statement: The authors declare that the research was conducted in the absence of any commercial or financial relationships that could be construed as a potential conflict of interest.

Copyright (c) 2017 Tang, Hu, Li, Win-Shwe and Li. This is an open-access article distributed under the terms of the Creative Commons Attribution License (CC BY). The use, distribution or reproduction in other forums is permitted, provided the original author(s) or licensor are credited and that the original publication in this journal is cited, in accordance with accepted academic practice. No use, distribution or reproduction is permitted which does not comply with these terms. 